\title{
Effect of Enzymatic Treatments on Physico-chemical Properties and Quality of Juice and Syrup of Some Date Fruits
}

\section{Ramadan, B.R. ${ }^{1}$; Magda A.A. Seleim ${ }^{1}$; E.A. Abdel-Rahman ${ }^{1}$ and Samar H. Abd Allah ${ }^{2}$}

${ }^{1}$ Food Sci. and Tech. Dept., Faculty of Agric., Assiut Univ.

${ }^{2}$ Food Sci. and Tech. Dept., Faculty of Agric.(New Valley branch), Assiut Univ.

\section{Abstract}

This work aims to benefit from low quality fruits (of Saidy, Tamr and Manthor dates) by the production of enzymatically treated syrup with high quality value. From the chemical analysis, the total and reducing sugars were the predominate components in all studied date fruits varied from 50.5 to $81.8 \%$ and from 40.5 to $57.7 \%$ dry weight basis (dwb), respectively. The total acidity (as malic acid) of the studied date fruits ranged from 0.14 to $0.22 \%$.

The effect of different concentrations of pectinase enzyme, 0.5-2.0\% on the efficiency of date juice extraction process and physico-chemical proprieties of the obtained date syrup were studied. The enzyme treated date juices recorded the lowest values of viscosity, turbidity and color ( as absorbance at $520 \mathrm{~nm}$ ), with the highest values of clarity compared with that of the untreated (control) samples. The results indicated that using $1 \%$ concentration of pectinase for $60 \mathrm{~min}$ at $50{ }^{\circ} \mathrm{C}$ gave a good result in terms of clarity, color and turbidity, but the recovery of total soluble solids was the highest after $90 \mathrm{~min}$ incubation time. The color values (as optical density at $420 \mathrm{~nm}$ ) of the enzyme-treated date syrups, Saidy, Tamr and Manthorranged from 0.499 to 0.574 compared with that of untreated date syrups which varied from 1.069 to 1.495 . The treated Saidy date syrup had the highest clarity value followed by Tamr and Manthor syrups. From the obtained results it can be concluded that the enzymatic treatments could be used to produce date syrup (Dibs) with good properties and high quality from second grade date fruits.

Keywords: Low quality Date fruits, pectinase enzyme, physico-chemical proprieties, Juice, Dibs.

\section{Introduction:}

Dates (Phoenix dactylifera L.) have been an important crop in the desert regions of Middle Eastern countries and formed the basis for survival of many ancient nomads, this continues to be true today (Mohammed, et al., 1983). The Arab countries produce about $74.5 \%$ of global date production. Egypt considered as the first country of the top ten date producers in world (FAO, 2015).

There is approximately two million tons per year, as wastes (fruits with imperfect appearance, secondary varieties not suitable for human consumption, and by-products from date processing) (FAO, 2015). 
Some researchers focused on the preparation of date syrup (AlFarsi, 2003, Al-Farsi et al., 2007, Fatma et al., 2011 and Enssaf et al., 2013). However, there are few studies dealing with this subject and are mainly limited to traditional processes. Pectinolytic and cellulolytic enzymes are used for the fruit processing industry to increase the extraction yield, reducing sugars, soluble dry matter and titrable acidity of the products from some fruits such as peaches, plums and apricots (Joshi et al. 1991). In the literatures, only few works have been reported regarding the effect of hydrolytic enzymes in the quality of date syrup (Al-Hooti et al., 2002). The low quality dates are a rich source of carbohydrates (73.3$89.55 \mathrm{~g} / 100 \mathrm{~g}$ dry matter) composed mainly of sugars and dietary fibers and are safe for human consumption (Besbes, et al., 2009). Owing to their composition, low quality dates were also used for preparation of some products with high value-added. The production of high quality date syrups using enzymatic treatment could give high value addition to the low quality dates (with hard texture). The aim of this work was to investigate the effect of enzyme (pectinase) treatments on composition and quality of date juice during the extraction process and to optimize process conditions. Furthermore, the effect of enzyme treatments on physico-chemical proprieties of the obtained date syrup was studied.

\section{Materials and Methods}

\subsection{Materials}

Dates samples: The second grade of date palm (PhoenixdactyleferaL.) fruits namely, Saidy and
Tamer as well the seedling (Manthor) fruits were obtained from the local market of El Kharja Osis - The New Vally governorate - Egypt, during the 2016 season, date fruit samples were collected at full maturity "Tamr stage".

Each of these fruits type was divided to three parts. The first part was used for some physical evaluations and the second part was directly cleaned, pitted and minced by meat mincer (Moulinex, type NE 401, France) before chemical analysis. The third part was prepared as above to obtained the date fruit paste and stored in polyethylene bags (about $500 \mathrm{~g}$ ) at $4 \pm 1^{\circ} \mathrm{C}$ until use in other treatments.

Enzyme and reagents: Commercial pectinase enzyme from $A s$ pergellusniger was purchased from Sigma-Aldrich. All other reagents used in these experiments were purchased from El-gomhouria Co. (Assuit - Egypt) and the redistilled water was used.

\subsection{Procedure}

2.2.1 Extraction of date juice by Enzyme treatments

The date paste was homogenized with water; the $\mathrm{pH}$ was adjusted to 4 using citric acid, before the addition of pectinase enzyme. Samples were mixed with enzyme concentrations of $0.5,1,1.5$ and $2 \%$ and placed in a water bath at $50{ }^{\circ} \mathrm{C}$ for 60,90 and $120 \mathrm{~min}$. Then the enzyme was deactivated by heating at $90{ }^{\circ} \mathrm{C}$ for $5 \mathrm{~min}$. and the date juice was extracted by a filtering cloth.

\subsubsection{Production of date} syrup

The clarified juices were concentrated by Rotary evaporator appa- 
ratus under similar conditions $\left(70^{\circ} \mathrm{C}\right.$ under vacuum of $500-600 \mathrm{~mm} / \mathrm{Hg}$ ) to produce date syrup of $70{ }^{\circ} \mathrm{Bx}$.

\subsection{Analytical methods}

\subsubsection{Physical characteristics of fruits}

The studied date fruit samples were prepared for general and physical inspections by dry cleaning and sorting as following: three samples were taken randomly and physically evaluated for insect infestation percentage, number of fruits per $\mathrm{Kg}$, mean weight of whole fruit, flesh and seed, fruit length and width at maximum circumference and seed length.

\subsubsection{Chemical composition}

Moisture, reducing - and total sugars, ash, crude protein, fiber and lipids were determined according to AOAC (2005). Non-reducing sugars were calculated by difference.

\subsubsection{Pectin content:}

The pectic acid content of date fruits flesh was determined by using Carry and Hayenz method (AOAC 2000). The diluted date extract treated by $\mathrm{CaCl}_{2}$ to precipitate $\mathrm{Ca}$ pectate. Pectic acid was determined as dry Ca-pectinatex 0.9235 .

\subsubsection{Tannins assay:}

Tannins in date flesh were determined according to LowenthalProcter method as applied by Tafti and Fooladi (2006). The diluted extract of date fruits was titrated by vs $0.1 \mathrm{~N} \mathrm{KMNO}_{4}$ in the presence of Indigo Carmine indicator. A blank (free of tannins) was prepared by treating the diluted extract with gelatin/charcoal was also titrated vs $0.1 \mathrm{~N}$ $\mathrm{KMNO}_{4}$ to correct for the actual tannin content.

\subsubsection{Viscosity:}

The relative viscosity of date juice was measured using an Ostwald capillary tube and the values were expressed as flow time (sec) at $25^{\circ} \mathrm{C}$. The relative viscosity was calculated by the following equation.

$$
\text { Relative viscosity } \eta_{r}=\frac{\eta}{\eta_{s}}
$$

Where; $\quad \eta=$ flow time of sample $\eta_{s}=$ flow time of water

\subsubsection{Clarity:}

Clarity was measured in date juice and the reconstituted juice from date syrups according to the method described by Endo (1965). The absorbance was measured at $660 \mathrm{~nm}$ and clarity was expressed as transmittance value $(\% \mathrm{~T})$.

\subsubsection{Turbidity:}

The turbidity index determinate according to ICUMSA method GS721 (1994).

\subsubsection{Color:}

The color was measured according to the method of Meydav et al., (1977) as follows: The sample date extract produced at room temperature $\left(25^{\circ} \mathrm{C}\right)$ by blender was centrifuged at $3300 \mathrm{rpm}$ for $20 \mathrm{~min}$. and the supernatant was diluted with an equal volume of alcohol (95\%) and filtered through Whatman paper No. 42.

The color was measured against alcohol (95\%). Browning was calculated as follows:

Browning $=$ Absorbance of diluted sample (5\% T.S.S.)at $420 \mathrm{~nm}$.

\subsubsection{TSS:}

Abbe refractometer was used to determine the TSS of samples according to A.O.A.C. (1990) at room temperature after calibration of the scale of the refractometer. 


\subsubsection{0 pH:}

The $\mathrm{pH}$ value was measured using a Beckman $\mathrm{pH}$ meter with a combination electrode at $25^{\circ} \mathrm{C}$ as described in the A.O.A.C. (1990).

\subsubsection{Total acidity:}

Total acidity (as malic acid) was determined according to A.O.A.C. (1990)

\section{Results and Discussion}

\subsection{Physical characteristics}

Data of some Physical characteristics of the studied date fruits were determined, and the results were presented in Table (1). Data showed that, Saidy date fruits was the highest in the Fruit weight (g), Flesh weight (g), Flesh/pits ratio, Fruit length $(\mathrm{mm})$ and fruit diameter(mm)values compared with the other studied date fruits. Tamr date fruits were the highest in pit weight (g), Flesh (\%) and Infestation (\%). Furthermore, Manthor date fruits were superior to all other varieties in fruits number/ $\mathrm{Kg}$ and Pit (\%). These differences were principally due to the hereditary aspects of palm tree, environment and the harvest time. These results were in agreement with those reported by Ramadan (1990, 1995 and 2000), ElSalhy (2000), Abdallah (2002), Osman (2008), Abd-Ellah (2009), Marzoukand Kassem (2010), Selim (2012) and Ramadan et al.(2016).

Table 1. Physical characteristics of the studied date samples.

\begin{tabular}{|l|c|c|c|}
\hline Characteristics & Saidy & Tamr & Manthor \\
\hline Fruits number/ Kg & 102 & 159 & 300 \\
\hline Fruit weight $(\mathrm{g})$ & 13.30 & 6.80 & 3.70 \\
\hline Flesh weight $(\mathrm{g})$ & 9.22 & 5.68 & 2.85 \\
\hline Pit weight $(\mathrm{g})$ & 1.34 & 1.38 & 0.80 \\
\hline Flesh/pits ratio & 6.90 & 4.10 & 3.60 \\
\hline Flesh (\%) & 69.30 & 83.5 & 77.00 \\
\hline Pit (\%) & 10.10 & 20.30 & 21.6 \\
\hline Fruit length (mm) & 3.30 & 3.10 & 3.00 \\
\hline Fruit diameter(mm) & 1.90 & 1.70 & 1.60 \\
\hline Infestation (\%) & 2.00 & 11.00 & 6.00 \\
\hline
\end{tabular}

\subsection{Chemical composition of the studied date fruits}

The gross chemical composition of studied date varieties was showed in Table 2. The moisture contents of Saidy, Tamr and Manthor fruits were 13.21, 10.72 and $8.12 \%$ (Table 1), respectively. These results are in agreement or even less than that reported by Ramadan (1990 and 1995), Hussein et al. (1999) and Hasnaoui et al. (2010). The moisture content of Saidy fruits was less than the recorded average in semi-dry varieties, this might be reasoned to a higher loss in its moisture content after harvesting during transportation, storage and marketing. Total sugars were the main components in all studied date fruits and varied from 50.5 to $81.5 \%$. Total and nonreducing sugars present in high amounts in Saidy date, while, reducing sugar was the predominant level in Tamr dates. The pectin content of date varied between 0.97 for Manthor and $1.47 \%$ for Tamr fruits. The crude protein content of 
the studied fruits ranged from 1.81 to $1.93 \%$. Mineral contents of Saidy, Tamr and Manthor dates were determined and the results obtained that Potassium level was the predominant among the determined elements, which was found with concentration varied from 109.37 to $157.34 \mathrm{mg} / 100 \mathrm{~g}$ of Saidy and Manthor date fruits, respectively (Table 3). Dates also contained ahigh levels of sodium and magnesium with concentrations ranged from 38.05 to $89.87 \mathrm{mg} / 100 \mathrm{~g}$ and 9.86 to 59.10 $\mathrm{mg} / 100 \mathrm{~g}$, respectively .

These results are similar to those reported by Ramadan (1990 and 1995), Tafti and Fooladi (2006), Besbes (2009), Borchani (2010), Selim (2012) and Ramadan et al. (2016).

Table 2. Mean values of gross chemical composition of the studied date fruits (dwb,except moisture).

\begin{tabular}{|l|c|c|c|}
\hline Components (\%) & Saidy & Tamr & Manthor \\
\hline Moisture & 13.21 & 10.72 & 8.12 \\
\hline Total sugars & 81.50 & 75.90 & 50.50 \\
\hline Reducing sugars & 41.70 & 57.70 & 40.50 \\
\hline Non-reducing sugars & 39.80 & 18.20 & 10.00 \\
\hline Crude protein & 1.93 & 1.86 & 1.81 \\
\hline Ash & 1.73 & 1.79 & 2.50 \\
\hline Crude lipids & 1.39 & 1.24 & 1.21 \\
\hline Total acidity (\% malic acid) & 0.14 & 0.19 & 0.22 \\
\hline Pectin & 1.05 & 1.47 & 0.97 \\
\hline Tannin & 0.12 & 1.05 & 2.50 \\
\hline
\end{tabular}

Table 3. Mineralcontent (mg/100g sample, dwb) of the studied date samples.

\begin{tabular}{|c|c|c|c|c|}
\hline \multicolumn{2}{|c|}{ Elements } & Saidy & Tamr & Manthor \\
\hline \multirow{3}{*}{ Macro-elements } & $K$ & 109.37 & 142.52 & 157.37 \\
\cline { 2 - 5 } & $M g$ & 9.86 & 14.38 & 59.10 \\
\cline { 2 - 5 } & $N a$ & 51.76 & 89.87 & 38.05 \\
\hline \multirow{3}{*}{ Micro-elements } & $F e$ & 15.10 & 11.76 & 16.48 \\
\cline { 2 - 5 } & $C u$ & 1.04 & 0.968 & 1.42 \\
\cline { 2 - 5 } & $M n$ & 1.59 & 0.645 & 1.04 \\
\cline { 2 - 5 } & $Z n$ & 0.774 & 1.12 & 6.35 \\
\hline
\end{tabular}

\subsection{Effect of enzymatic extraction on date juices}

The effect of pectinase enzyme concentration $(0.5,1,1.5$ and $2 \%)$ and extraction time $(30,60,90$ and $120 \mathrm{~min})$ at optimization temperature of enzyme $50^{\circ} \mathrm{C}$ on the total soluble solids (TSS), Clarity $(660 \mathrm{~nm})$, Viscosity, Optical density and Turbidity of obtained Saidy fruits juice are shown in Figures 1-5.

The results of the enzyme treatment at $50^{\circ} \mathrm{C}$ achieved an increase in the total soluble solids of extracted juices about 7.0-9.5\%, in particular, at 60 and $90 \mathrm{~min}$ by enzyme concentrations 1.5 and $2.0 \%$, respectively (Figure 1). While the concentration of enzyme $0.5 \%$ have a 
lower recovery values of TSS at all varies time incubations at the same temperature. As enzyme dose increased, juice extraction improved and more TSS value could be recovered at the same time and temperature. On the other hand the TSS recovery of the extracted date juice was gradually increased (from 14.7 to $22.2 \%$ ) with the extraction time increasing (from 1 to $2 \mathrm{~h}$, respectively) compared with the control at the same enzyme concentration (1.5\%). Al- Hooti et al. (2002) employed ex- traction procedures for producing date syrup and reported that the use of pectinase/cellulose enzymes gave the highest recovery of TSS value (68\%) compared with control without these enzymes (35\%). Khalil et al. (2002) used Ultrazyme-100G for extraction of juice from Siwi date pulp at different concentrations. This was related to the degradation of the pectin in the plant cell wall matrix and in the middle lamella into galacturonic acid units and sugars (Demir et al. 2001 and Landbo et al., 2007).

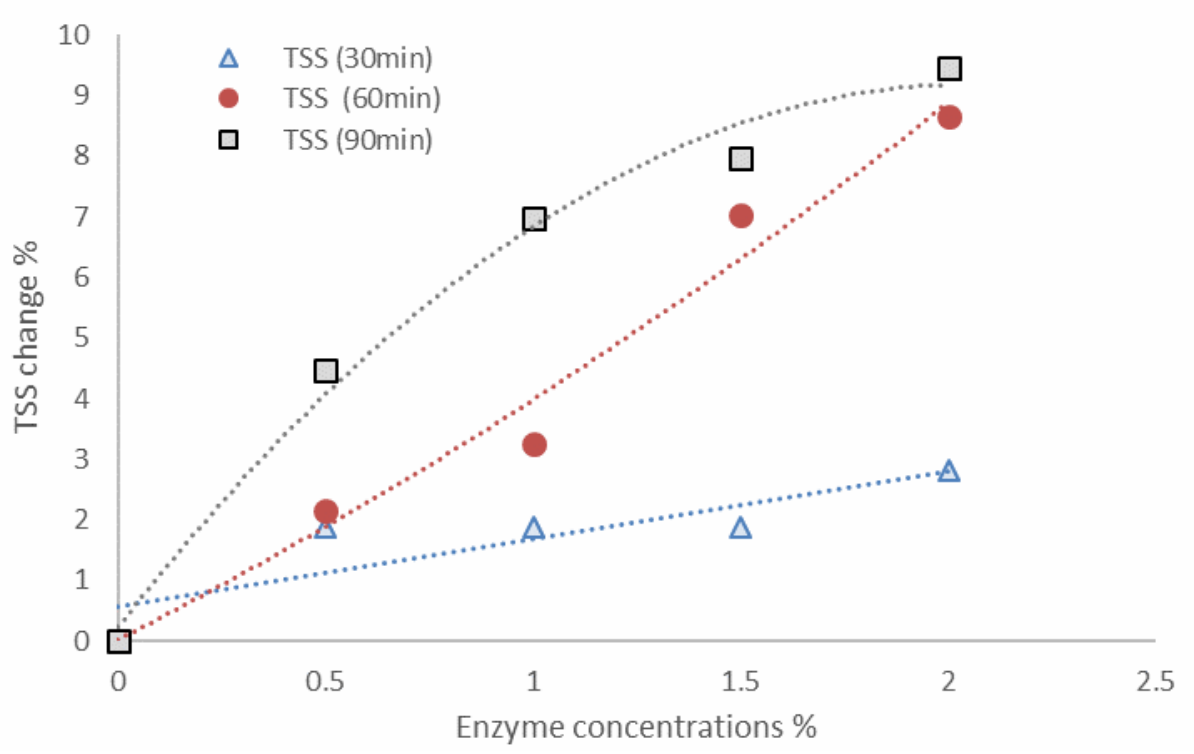

Figure (1): Effect of pectinase enzyme concentration and extraction time at $50^{\circ} \mathrm{C}$ on the TSS of Saidy date juices.

The results indicated that enzyme treatment of date pulp greatly improved the clarity, viscosity, turbidity and color as optical densityat $520 \mathrm{~nm}$ of the resulted juice. The results in Figure 2 showed that when the enzyme dose increased from 0.5 to $2 \%$, clarity values of the treated samples expressed as $\mathrm{T} \%$ at $660 \mathrm{~nm}$ were increased from 79.3 to $85.5 \%$, respectively after $60 \mathrm{~min}$ incubation compaired with the control (50.4\%). The clarity value, also increased with incubation time progress. This observation might be due to the action of pectic enzyme in breaking down the linkage between pectin and cellulose. From Figure 3, it was clear that the relative viscosity (nr) of the produced juice gradually decreased from 0.78 to 0.45 after $60 \mathrm{~min}$ incubation with increasing the enzyme concentration 
from 0.5 to $2 \%$, respectively compaired with the relative viscosity of untreated juice (1.31). Additionally, the relative viscosity decreased from 0.96 to 0.74 and 1.20 to 0.85 at 0.5 to $2 \%$ enzyme concentration after 90 and 120 min incubation, respecitvely.
The result indicated that the best enzyme concentrations were 1.5 and $2 \%$ at $60 \mathrm{~min}$ of extraction time to improve the viscosity of the extracted date juices by decreasing about 57.6 and $66 \%$, respectively.

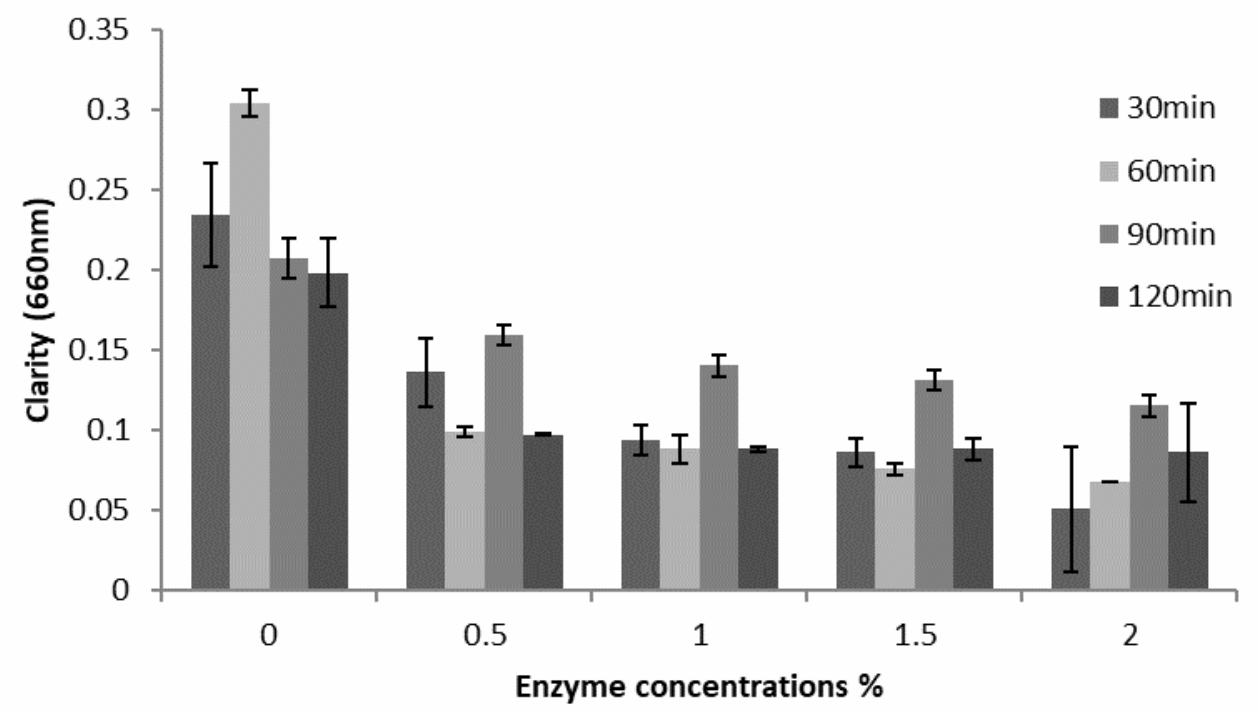

Figure (2): Effect of pectinase enzyme concentration and extraction time at $50^{\circ} \mathrm{C}$ on the Saidy dates juice clarity $(660 \mathrm{~nm})$.

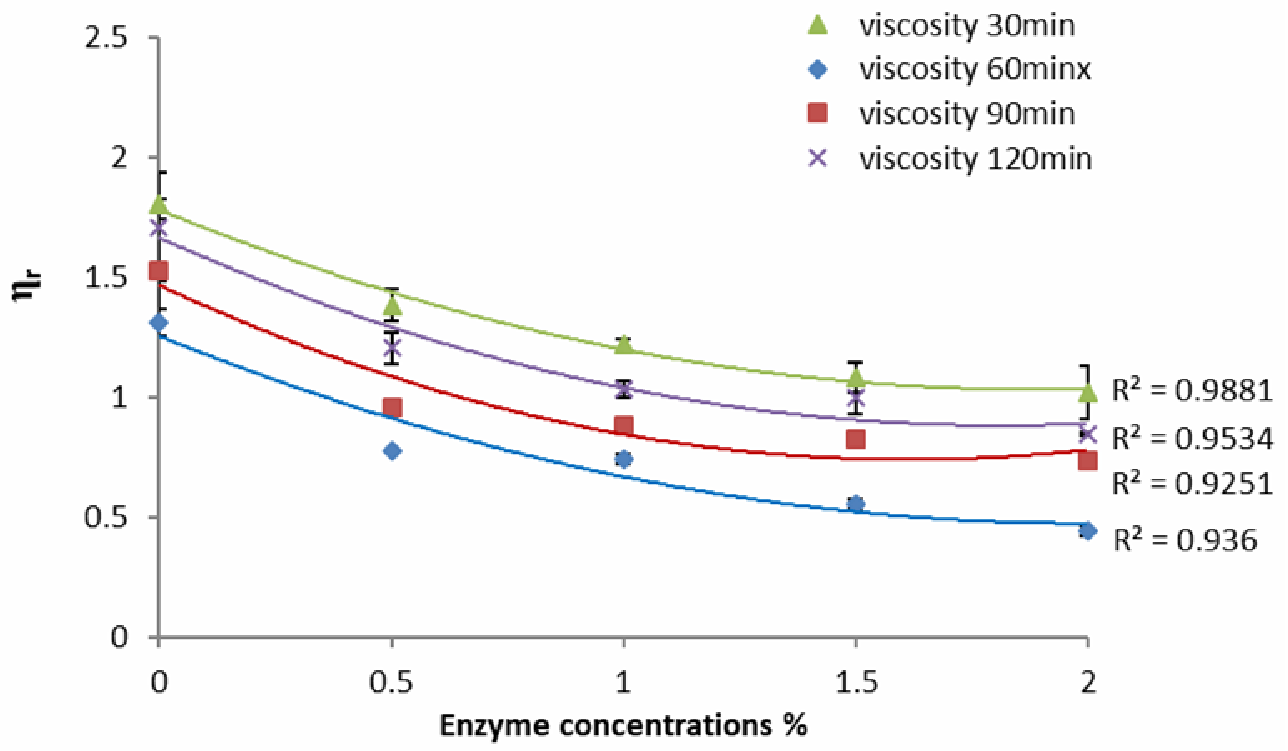

Figure (3): Effect of pectinase enzyme concentration and extraction time at $50^{\circ} \mathrm{C}$ on the Saidy dates juice relative viscosity.

The results as shown in Figure 4 proved that enzyme treatment 0.5 , $1.0,1.5$ and $2.0 \%$ of Saidy date fruits led to color removal by $56.50,64.23$, 58.17 and $66.08 \%$ (as O.D at 520nm), respectively. These results are simil- 
lar to that obtained by Al-Hooti et al. (2002). As shown in Figure 5, the turbidity decreased with increase in enzyme concentration. In fact, the result of turbidity measurment indicated that the highest effect of enzyme treatment was at the extraction time of $60 \mathrm{~min}$ of all enzyme concentration treatments. Where the turbid- ity decreased by $66,71,76$ and $79 \%$ of enzyme concentration $0.5,101,1.5$ and $2 \%$, respectively. The reduction of the turbidity is probably due to pectin hydrolysis in the plant cell wall matrix and in the middle lamella allowing liberation of galacturonic acid (Albagnac et al., 2002).

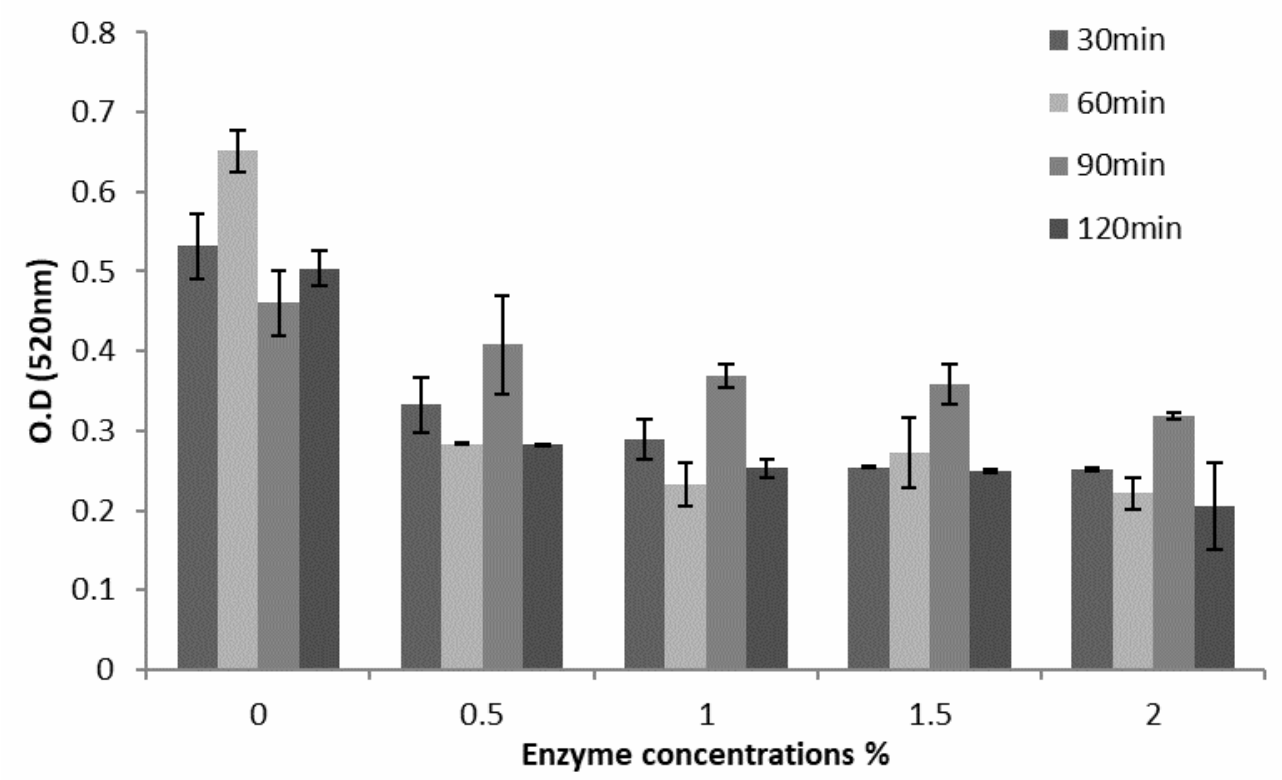

Figure (4): Effect of pectinase enzyme concentration and extraction time at $50^{\circ} \mathrm{C}$ on the Saidy dates juice optical dinsity (520nm).

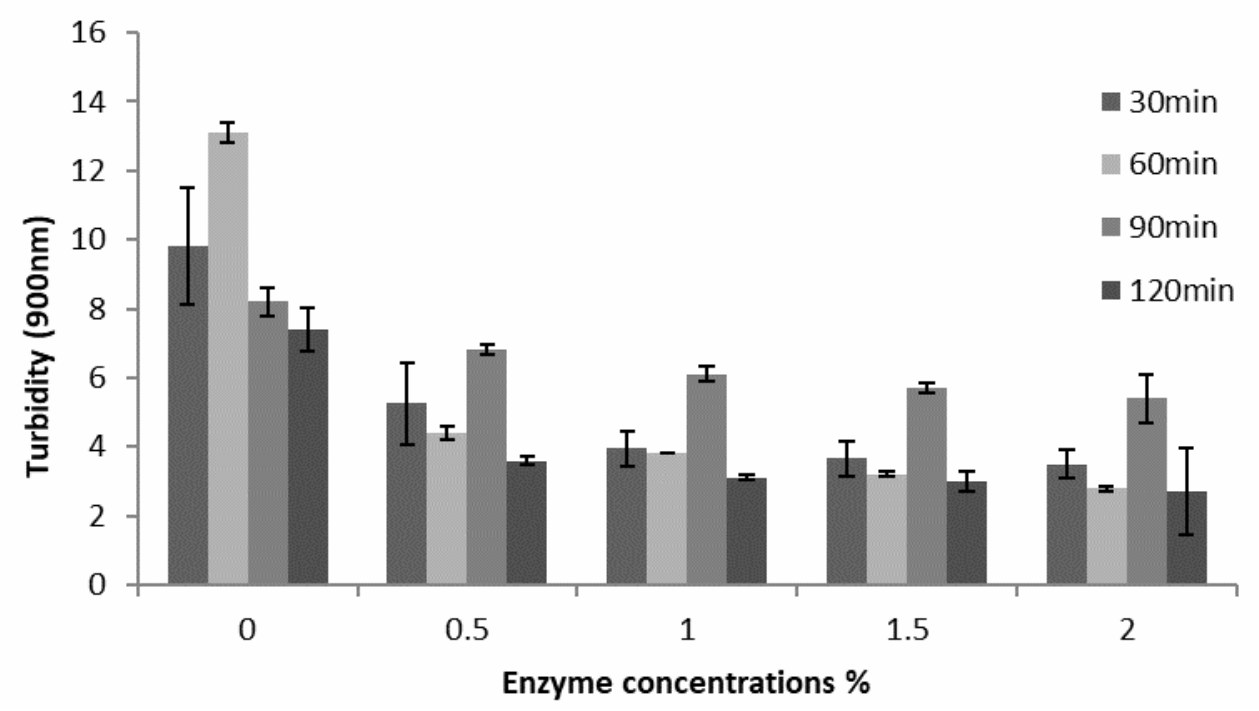

Figure (5): Effect of pectinase enzyme concentration and extraction time at $50^{\circ} \mathrm{C}$ on the Saidy dates juice turbidity $(900 \mathrm{~nm})$. 
The influence of pectinase enzyme treatment, $1 \%$ at $50^{\circ} \mathrm{C}$ and incubation time $60 \mathrm{~min}$, on the date juices characteristics of different date varieties, Saidy, Manthor and Tamr was investigated. The result was shown in Figure 6 indicated that the recovery of TSS increased by $6.0,5.6$ and $6.6 \%$ of Saidy, Manthor and Tamr, respectively. An addition, the highest effect of enzyme treatment was in the juice clarity of Saidy $(60 \%$ decrease) followed by Manthor (41\% decrease) and Tamr (13\% decrease) at the same condition. Also, the percentage of color removal (as optical density at $520 \mathrm{~nm}$ ) and turbidity of treated Saidy juice were 66 and $71 \%$, respectively. Manthor variety gave a good result of enzyme effect on juice relative viscosity $\left(\eta_{\mathrm{r}}\right)$ compared with Saidy and Tamr.

Table 4. Effect of enzyme treatment on physical proparties of juices after 60 min of incubation and $1 \%$ enzyme concentration at $50^{\circ} \mathrm{C}$ for Tamr and Manthor dates fruits.

\begin{tabular}{|l|c|c|c|c|c|c|}
\hline $\begin{array}{c}\text { Enzyme } \\
\text { Concentration\% }\end{array}$ & TSS $\left({ }^{\circ} \mathbf{B x}\right)$ & $\mathbf{p H}$ & Clarity(660nm) & Viscosity & OD(520nm) & Turbidity(900nm) \\
\hline \multicolumn{7}{|c|}{ Tamr } \\
\hline Untreated juice & 18.2 & 4.40 & 64.12 & 2.41 & 0.388 & 0.085 \\
\hline Treated juice & 19.4 & 4.38 & 72.28 & 1.98 & 0.324 & 0.061 \\
\hline \multicolumn{7}{|c|}{ Manthor } \\
\hline Untreated juice & 18 & 4.37 & 52.6 & 2.96 & 0.612 & 0.117 \\
\hline Treated juice & 19 & 4.33 & 74.3 & 1.89 & 0.345 & 0.049 \\
\hline
\end{tabular}

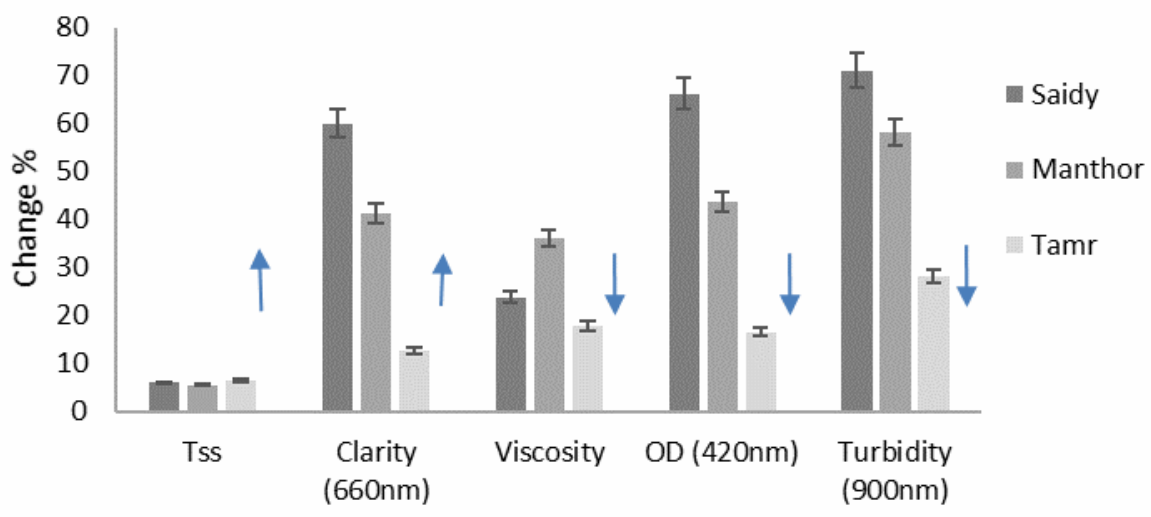

Characteristics

Figure (6): Effect of pectinase enzyme on physical proparties of juices after 60 min of incubation and $1 \%$ enzyme concentration at $50^{\circ} \mathrm{C}$ for Tamr and Manthor dates fruits

\subsection{Physico-chemical characteris- tics of dibs}

Two samples of Saidy, Tamr and Manthor date syrup produced by concentration by rotary evaporator under vacuum (treated $\left(\mathrm{T}_{1}\right)$ and untreated $\left(\mathrm{T}_{0}\right)$ with pectinase enzyme). Those samples were evaluated for 
their physico-chemical characteristics. Acidity, pH, TSS, color (absorbance at $420 \mathrm{~nm}$ ) and clarity were determined in the syrup samples, as well as total sugars, ash, protein and total phenols content. The obtained results are presented in Table (7).

Table 5. Physicochemical characteristics of dibs produced from treated and untreated Saidy, Tamr and Manthor date juices (wwb \%):

\begin{tabular}{|l|c|c|c|c|c|c|}
\hline \multirow{2}{*}{ Characteristics } & \multicolumn{2}{|c|}{ Saidy } & \multicolumn{2}{c|}{ Tamr } & \multicolumn{2}{c|}{ Manthor } \\
\cline { 2 - 7 } & $\mathbf{T}_{\circ}$ & $\mathbf{T}_{\mathbf{1}}$ & $\mathbf{T}_{\mathrm{o}}$ & $\mathbf{T}_{\mathbf{1}}$ & $\mathbf{T}_{\circ}$ & $\mathbf{T}_{\mathbf{1}}$ \\
\hline Total soluble solids \% & 70.00 & 72.50 & 68.50 & 72.50 & 68.00 & 72.00 \\
\hline Total sugars \% & 67.86 & 72.00 & 60.43 & 63.00 & 57.69 & 72.67 \\
\hline Reducing sugars \% & 63.75 & 67.86 & 51 & 53.13 & 49.04 & 84.77 \\
\hline Non- reducing sugars \% & 4.11 & 4.14 & 9.43 & 9.87 & 7.90 & 8.65 \\
\hline Acidity (as acetic acid \%) & 0.39 & 0.90 & 0.59 & 1.59 & 0.79 & 1.10 \\
\hline pH & 5.34 & 5.14 & 5.06 & 4.91 & 5.08 & 5.00 \\
\hline Ash\% & 1.70 & 1.50 & 2.60 & 2.40 & 1.90 & 1.70 \\
\hline OD $($ A at 420 $\mathrm{nm})$ & 0.77 & 0.52 & 1.45 & 0.57 & 1.06 & 0.49 \\
\hline Clarity $($ A at $660 \mathrm{~nm})$ & 0.22 & 0.1 & 0.58 & 0.14 & 0.82 & 0.16 \\
\hline Total phenols $\mathrm{mg} / \mathrm{g}$ & 104.97 & 57.25 & 136.07 & 93.57 & 247.31 & 91.29 \\
\hline
\end{tabular}

The mineral composition of date syrup was dominated by sodium (436.99- 244.97-420.7 mg/100g) for the enzyme-treated date syrup $\left(\mathrm{T}_{1}\right)$ of Saidy, Tamr and Manthor dates, respectively and $(53.71,49.16$ and $80.52 \mathrm{mg} / 100 \mathrm{~g} \mathrm{wwb}$ ) for control samples $\left(\mathrm{T}_{0}\right)$ followed by potassium $(413.33-362.42 \mathrm{mg})$ for $\left(\mathrm{T}_{1}\right)$ and (237.61-511.01-822.42 $\mathrm{mg} / 100 \mathrm{~g}$ ) for
$\left(\mathrm{T}_{0}\right)$, calcium and phosphorus. The results are in the line with those reported by Al-Hooti et al. (2002) who found that, sodium concentration was the greatest followed by potassium, calcium, and magnesium as the second. However, Fatma et al. (2011) found that potassium was the greatest followed by calcium, phosphorus and magnesium.

Table 6. Mean values of mineral contents $(\mathrm{mg} / 100 \mathrm{~g}$ sample, wwb) of the studied date syrups.

\begin{tabular}{|c|c|c|c|c|c|c|c|}
\hline \multirow{2}{*}{ Elements } & \multicolumn{2}{c|}{ Saidy } & \multicolumn{2}{c|}{ Tamr } & \multicolumn{2}{c|}{ Manthor } \\
\cline { 3 - 8 } & $K$ & 237.61 & 413.33 & 511.01 & 362.42 & 822.42 & 675.01 \\
\hline \multirow{4}{*}{ Macro-elements } & $C a$ & 43.99 & 56.13 & 75.68 & 111.60 & 107.12 & 80.73 \\
\cline { 2 - 8 } & $M g$ & 46.47 & 49.89 & 45.37 & 50.06 & 47.56 & 44.89 \\
\cline { 2 - 8 } & $N a$ & 53.71 & 436.99 & 49.16 & 244.97 & 80.52 & 420.7 \\
\cline { 2 - 8 } & $F e$ & 10.48 & 10.19 & 10.52 & 10.77 & 11.02 & 13.50 \\
\hline \multirow{4}{*}{ Micro-elements } & $P$ & 76.69 & 71.01 & 74.37 & 129.46 & 88.95 & 84.78 \\
\cline { 2 - 8 } & $M n$ & 0.58 & 0.82 & 1.82 & 0.59 & 0.52 & 0.51 \\
\cline { 2 - 8 } & $Z n$ & 0.56 & 0.75 & 0.69 & 1.00 & 0.59 & 0.72 \\
\hline
\end{tabular}

$\mathbf{T}_{\mathbf{1}}$ : Enzyme treated samples $\quad \mathbf{T}_{\mathbf{0}}$ : Untreated samples (control) 


\section{References}

Abdallah, A. A. (2002). Evaluation and identification of some local date palm cultivars at Rubatab area, M.Sc. These, Nile Valley Univ., Sudan.

Abd-Ellah, A. E. I. (2009). Chemical and technological studies on some Sudanese date cultivars. Ph.D. Thesis, College, of Graduate Studies, Nile Valley Univ., Sudan.

Albagnac, G., Varoquaux, P. and Montigaud, J.C, (2002). Technologies de transformation des fruits. Paris: Editions Tec. \& Doc., pp: 324-431.

Al-Farsi, M. A.; Alasalvar, C., Al-Abid, M., Al-Shoaily, K., Al-Amry, M. and Al-Rawahy, F. (2007). Compositional and functional characteristics of dates, syrups, and there by-products. Food Chem., 104: 943-947.

Al-Farsi, M.A., (2003). Clarification of date juice. Inter. J. Food Sci. Techn., 38: 241-245.

Al-Hooti, S., Sidhu, J. S., Al-Saqer, J. M., and Al-Othman, A. (2002). Chemical composition and quality of date syrup as affected by pectinase/cellulase enzyme treatment. Food Chem., 79.215-220.

AOAC (1990). Association of Official Analytical Chemists. Official methods of analysis. Arlington, USA.

AOAC (2000). Official methods of the Association of Official Analytical Chemists, $17^{\text {th }}$ Ed, Washington, DC, USA.

AOAC (2005). Official Methods of the Association of Official Analytical Chemists, $16^{\text {th }}$ Ed, Washington, DC, USA.

Besbes, S., L. Drira, C. Blecker, C. Deroanne and H. Attia, (2009). Adding value to hard date (Phoenixdactylifera L.): compositional, functional and sensory characteris- tics of date jam. Food Chem., 112: 406-411.

Borchani, C.; Besbes, S.; Blecker, C.; Masmoudi, M.; Baati, R. and Attia, H. (2010). Chemical properties of 11 date cultivars and their corresponding fiber extracts. African J. of Biotech., 9(26): 4096-4105.

Demir, N., J. Acar, K. Sarioğlu and M. Mutlu, (2001). The use of commercial pectinase in fruit juice industry. Part 3: immobilized pectinase for mash treatment. J. Food Eng., 47: 275-280.

El-Salhy, A. M. (2000). Effect of bagging the spates on Zaghloul date productive under Assiut conditions. Assiut J. Agric. Sci., 31(30): 123-134.

Endo, A. (1965). Studies on pectolytic enzymes of molds. Part xv.Effects of $\mathrm{pH}$ and some chemical agents on the clarification of apple juice. Agric. Biol. Chem., 29:222.

Enssaf M.A. El-Hamzy, M.M.S. Ashour, R.K. Moawad and G.M. Abd El Moniem (2013). Physico-chemical, sensorial and antioxidative characteristics of date syrups as affected by pectinase/cellulase enzymes treatments. J. of Applied Sci. Research, 9 (11): 5835-5849.

FAO (2015). Statistical databases. http://faostat.fao.org.

Fatma Abbès, Mohamed A. Bouaziz, Christophe Blecker, Manel Masmoudi, Hamadi Attia, Souhail Besbes (2011). Date syrup: Effect of hydrolytic enzymes (pectinase/cellulase) on physicochemical characteristics, sensory and functional properties. LWT - Food Science and Technology 44:18271834.

Hasnaoui, A., El-Houmaizi, M. A., Asehraou, A., Sindic, M., Deroanne, C. and Hakkou, A. (2010). Chemical composition and microbial quality of dates grown in Figuid of 
Morocco. Inter. J. Agric. and Biol., 12: 311-314.

Hussein, I. A.; Bakr, E. L. and Osman, S.M. (1999). Effect of pollen source on physical and chemical fruit characteristics of date palm. Zagazig J. Agric. Res., 26(4).

ICUMSA (1994). international commission for uniform methods of sugar analysis.GS7-21.

Joshi, V.K., Chauhan. S. Kand Lal. B.B, (1991). Extraction of juices from peaches, plums and apricots by pectinolytic treatment. J. Food Sci. Techn., 28(1): 64-65.

Khalil, K. E., Abd-El-Bari, M. S., Hafiz, N. E. and Ahmad, E. Y., (2002). Production, evaluation and utilization of date syrup concentrate (dibis). Egyptian J. of Food Sci. 30: 2, 179-203.

Landbo, A.K., Kaack,K and Meyer.A.S, (2007). Statistically designed two step response surface optimization of enzymatic prepress treatment to increase juice yield and lower turbidity of elderberry juice.Innov. Food Sci. Emer. Techn., 8: 135142.

Marzouk, H. A. and Kassem, H. A. (2010). Improving fruit quality, nutritional value and yield of Zaghloul dates by application of organic and or mineral fertilizers. Scientia Hortculturae, 127: 249254.

Meydav, S.; Saguy, I. and Kopelman, I. J. (1977). Browning determination in citrus products. J. Agric. Food Chem., 25(3), 802-804.

Mohammed, S., Shabana, H. R., and Mawlod, E. A. (1983). Evaluation and identification of Iraqi date cul- tivars: fruit characteristics of fifty cultivars. Date Palm J., 2(1), 2755.

Osman, S. M. (2008). Fruit quality and general evaluation of Zaghloul and Samany date palm cultivars grown under condition of Aswan. American Eurasian, J. of Agric. and Environ. Sci., 4 (2): 230-236.

Ramadan, B. R. (1990). Chemical and technological studies on some New Valley dates. M.Sc. Thesis, Fac. of Agric., Assiut Univ., Egypt.

Ramadan, B. R. (1995). Biochemical, nutritional and technological studies on dates. Ph.D. Thesis, Fac., of Agric., Assiut Univ., Egypt.

Ramadan, B.R. (2000). Storage stability and utilization of date syrup (Dibs). $1^{\text {st }}$ mansoura conf. of Food Sci. and Dairy Tech., 17- 19 October.

Ramadan, B. R., El-Rify, M. N. A., Abd El-Hamid, A. A. and Abd ElMajeed, M.H.(2016). Effect of some treatments on chemical composition and quality properties of Saidy date fruit (Phoenix dactylifera L.) during storage. Assiut J. Agric. Sci., 47(5): 107-124.

Selim, K.; Abdel-Bary, M. and Ismael, O. (2012). Effect of irradiation and heat treatments on the quality characteristics of Siwy date fruit (Phoenixdactylifera L.). AgroLife Sci. J., 1: 103-111.

Tafti, A. G. and Fooladi, M. H. (2006). A study on the physico-chemical properties of Iranian Shamsaei date at different stages of maturity. World J. of Dairy and Food Sci., 1(1): 28-32. 
تأثير المعاملات الإنزيمية علي الخواص الفيزوكيميائية وجودة العصير والابس الناتج من ثُمار بعض التمور

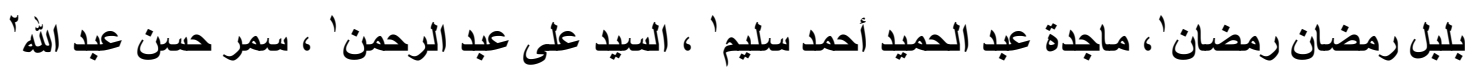

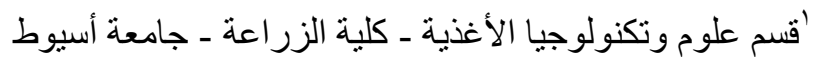

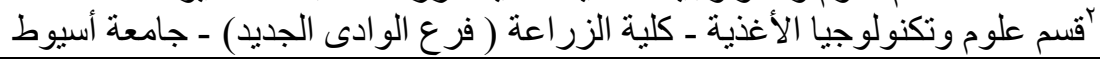

تهدف هذه الدر اسة إلى الإستفادة من الثمار المنخفضة الجودة (من البلح الصعيدى، التهر

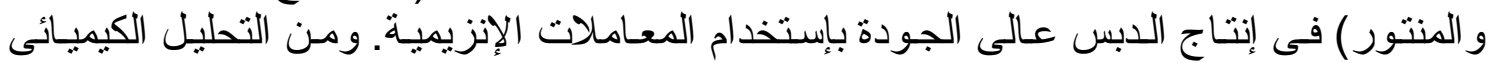

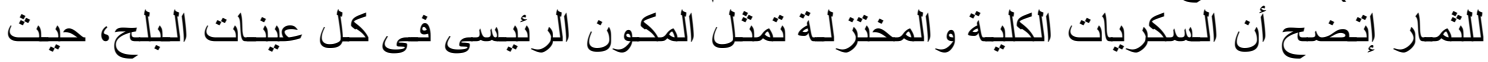

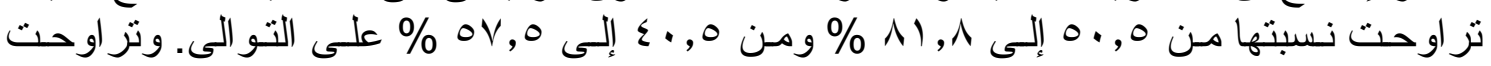

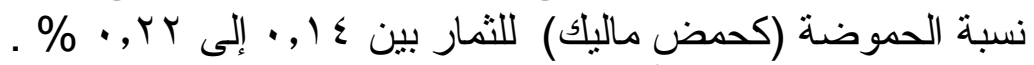

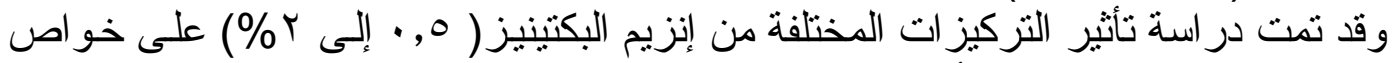

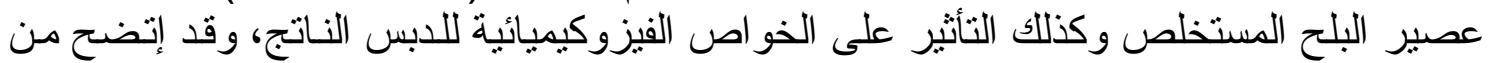

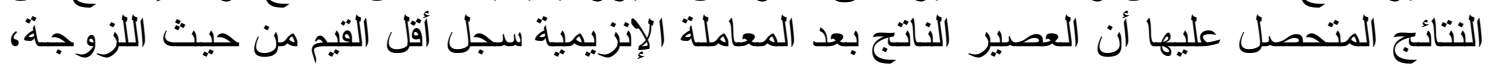

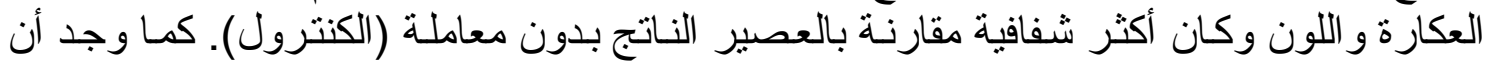

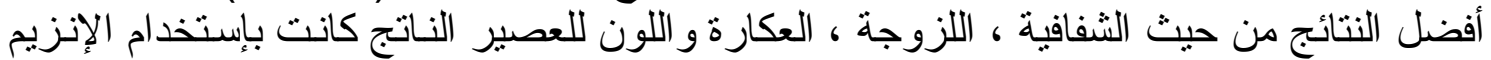

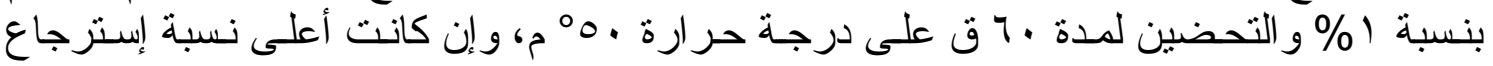

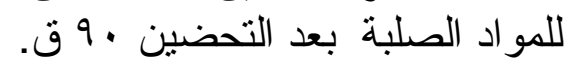

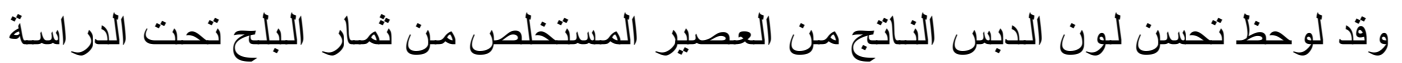

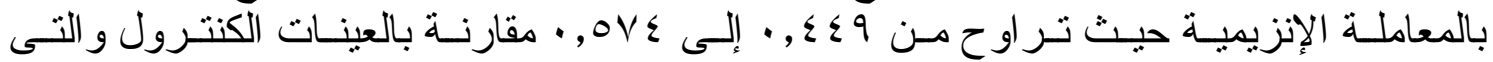

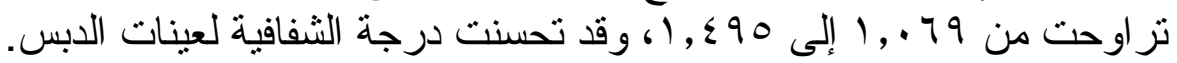

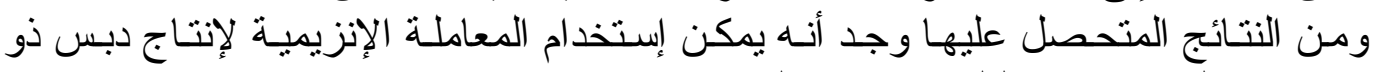
خو اص وجودة عالية من ثمار البلح منخفضة الجودة. 